\title{
Catabolism of Adenosine 5'-Monophosphate by Extracts of the Marine Bacterium Beneckea natriegens
}

\author{
By DONALD F. NIVEN,* PAULINE A. COLLINS \\ AND CHRISTOPHER J. KNOWLES \\ Biological Laboratories, University of Kent, \\ Canterbury $\mathrm{CT}_{2} 7_{\mathrm{NJ}}$
}

(Received 25 November 1976)

\begin{abstract}
SUM M A R Y
AMP is catabolized by cell-free extracts of Benecked natriegens to inosine via adenosine by AMP nucleotidase and adenosine deaminase. In the presence of ATP, the AMP nucleotidase is inhibited and an AMP deaminase is activated, resulting in formation of IMP. When low concentrations of ATP are used, the IMP is converted, simultaneously with ATP consumption, to inosine by IMP nucleotidase, which is presumably ATP-sensitive. Since $5^{\prime}$-nucleotidases from various organisms are known to catabolize several ribonucleoside monophosphates, the AMP and IMP nucleotidase activities of $B$. natriegens may be due to the same enzyme. CTP, GTP and UTP inhibit AMP nucleotidase from $B$. natriegens without stimulating AMP deaminase, thus severely decreasing the rate of AMP breakdown.
\end{abstract}

\section{INTRODUCTION}

Whereas other aspects of adenine nucleotide metabolism by living organisms have been extensively investigated, there have been relatively few studies of AMP catabolism, particularly in bacteria (Drummond \& Yamamoto, 197I). Possible pathways of AMP catabolism are shown in Fig. I.

AMP nucleotidase has been found in several bacteria (Kohn \& Reis, I963; Heppel, 1971; Felicioli et al., 1973) and, where studied, it has been shown to be located in the periplasm (Heppel, 197I). In Escherichia coli it is involved in the uptake of exogenous AMP (Yagil \& Beacham, 1975). Mutants of E. coli deficient in AMP nucleotidase are unable to take up AMP but are otherwise able to grow normally: therefore, this enzyme probably does not have an essential role in the catabolism of intracellular AMP (Yagil \& Beacham, 1975).

In Azotobacter vinelandii, AMP is degraded to adenine by AMP nucleosidase, and then to hypoxanthine by adenine deaminase (Hurwitz, Heppel \& Horecker, I957; Schramm \& Leung, 1973; Schramm \& Lazorik, 1975). Escherichia coli contains AMP nucleosidase but not adenine deaminase (Koch \& Vallee, 1959; Schramm \& Lazorik, 1975). In contrast, AMP nucleosidase has not so far been found in any eukaryotes (Schramm \& Leung, 1973). In mammalian tissues AMP is catabolized to inosine by AMP deaminase and IMP nucleotidase and/or by AMP nucleotidase and adenosine deaminase (Burger \& Lowenstein, 1967; Woods, Eggleston \& Krebs, I970; Drummond \& Yamamoto, I97I). AMP deaminase has been extensively purified from several eukaryotes and its properties have been studied (cf. Smith \& Kizer, 1969; Boosman \& Chilson, I976; Makarewicz \& Stankiewicz, 1976).

* Present address: Department of Microbiology, Macdonald Campus of McGill University, Macdonald College P.O., Province of Quebec HoA I Co, Canada.

Vol. 99, No. 2 was issued 3 May, 1977 


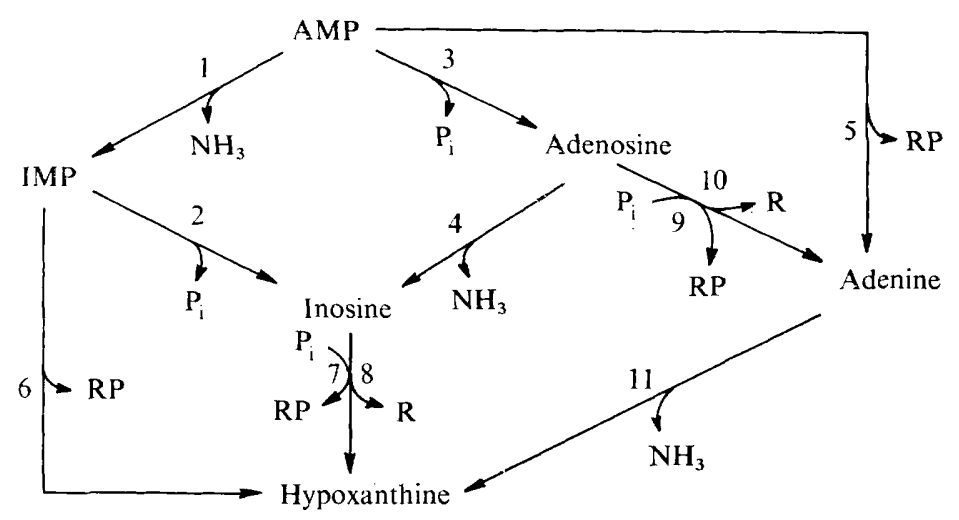

Fig. I. Possible pathways of AMP catabolism. AMP, adenosine 5'-monophosphate; IMP, inosine 5 '-monophosphate; $\mathrm{R}, \mathrm{D}(-)$-ribose; $\mathrm{RP}$, ribose 5-phosphate; $\mathrm{P}_{\mathrm{i}}$, inorganic phosphate.

Enzymes: I, AMP deaminase (EC 3.5.4.6); 2, IMP nucleotidase (EC 3.1.3.5); 3, AMP nucleotidase (EC 3.I.3.5); 4, adenosine deaminase (EC 3.5.4.4); 5, AMP nucleosidase (EC 3.2.2.4); 6, IMP nucleosidase (EC 3.2.2 . 12); 7, inosine phosphorylase (EC 2.4.2.1); 8, inosine nucleosidase (EC 3.2.2.2); 9, adenosine phosphorylase (EC 2.4.2.1); IO, adenosine nucleosidase (EC 3.2.2.7); I I, adenine deaminase (EC 3.5.4.2).

Though a non-specific adenine nucleotide deaminase (EC 3.5.4.17) has been found in Desulfovibrio desulfuricans (Yates, 1969), there have been no reports of the presence of AMP deaminase in bacteria.

Overall metabolic activity of growing organisms is controlled by the action of ATP, ADP and AMP as allosteric effectors of a wide range of enzymes (Atkinson, 1968; Knowles, 1977). The size of the adenine nucleotide pool and its proportional make-up, expressed as an energy charge of 0.8 to 0.9 , are strictly controlled during growth of bacteria (Chapman, Fall \& Atkinson, I97I; Niven, Collins \& Knowles, I977; Knowles, 1977).

Does AMP catabolism have a role in maintaining the adenine nucleotide pool during growth? If not, how is its breakdown regulated so that depletion of the adenylates does not,occur? Liver AMP deaminase and AMP nucleosidase from $A$. vinelandii are activated by a decrease in energy charge (see Atkinson, 1968) and inhibited by inorganic phosphate (Chapman \& Atkinson, 1973; Schramm \& Leung, 1973). It has been postulated that these enzymes have a similar role of temporarily protecting metabolic activity of the tissue or organism by causing a transient decrease in the total adenine nucleotide pool size and thus maintaining energy charge under conditions of environmental stress (Chapman \& Atkinson, 1973; Schramm \& Leung, 1973).

Recent experiments on the adenine nucleotide content of growing Beneckea natriegens have shown that, on starvation, the energy charge is maintained at the growth value of about 0.9 for several hours and there is little decrease in total nucleotide content (Niven et al., I 977). We have therefore examined the pathways of AMP catabolism by B. natriegens in order to determine how the adenine nucleotide content is regulated. This paper reports that AMP is broken down to inosine via adenosine by AMP nucleotidase and adenosine deaminase but, in the presence of ATP, it is broken down to IMP by AMP deaminase. AMP deaminase has not previously been observed in a bacterium. 


\section{METHODS}

Organism and growth conditions. Beneckea natriegens strain III was grown in a defined medium (Niven et al., 1977) containing $10 \mathrm{~mm}$-sodium succinate. Overnight starter culture $(8 \mathrm{ml})$ was inoculated into $400 \mathrm{ml}$ fresh medium in 21 baffled flasks and grown at $35^{\circ} \mathrm{C}$ on a rotary shaker $\left(200 \mathrm{rev} . \mathrm{min}^{-1}\right)$. Bacteria were harvested in the mid-exponential phase of growth $\left(E_{680 \mathrm{~nm}}\right.$ approx. 0.7 in $10 \mathrm{~mm}$ cuvettes in a Pye Unicam SP500 spectrophotometer).

Preparation of extracts. Bacteria from four $400 \mathrm{ml}$ cultures were centrifuged at $23000 \mathrm{~g}$ for $10 \mathrm{~min}$, washed with $50 \mathrm{ml} 100 \mathrm{~mm}$-triethanolamine/ $\mathrm{HCl}$ containing $300 \mathrm{~mm}-\mathrm{NaCl}$, $30 \mathrm{mM}-\mathrm{KCl}, 2 \cdot 22 \mathrm{mM}-\mathrm{MgSO}_{4}, \mathrm{O} \cdot \mathrm{I} \mathrm{mM}-\mathrm{Na}_{2} \mathrm{EDTA}, \mathrm{O} \cdot \mathrm{I}$ mM-dithiothreitol, and $3 \mu \mathrm{M}$-phenylmethylsulphonyl fluoride ( $\mathrm{pH} \mathrm{8.0)}$, and resuspended in $3 \mathrm{ml}$ fresh buffer. Bacteria were disrupted by sonication (MSE sonicator, $150 \mathrm{~W}, 4 \times 15 \mathrm{~s} 0{ }^{\circ} \mathrm{C}$ ) and, after centrifuging at $12000 \mathrm{~g}$ for $10 \mathrm{~min}$ at $4{ }^{\circ} \mathrm{C}$, the cell-free extract was either dialysed overnight against $500 \mathrm{ml}$ fresh buffer at $4{ }^{\circ} \mathrm{C}$ or fractionated into particulate and supernatant fractions as described previously (Weston \& Knowles, 1973, 1974). The particulate fraction was resuspended in I $\mathrm{ml}$ fresh buffer and the particulate and supernatant fractions were dialysed as above. Protein was assayed by the modified biuret method (Gornall, Bardawill \& David, 1949).

Determination of enzyme activities. Adenine, adenosine and AMP deaminases were assayed as described by Schramm \& Lazorik (1975) except that the reaction mixture contained (in $\mathrm{I} \cdot 5 \mathrm{ml}$ ) either dialysed cell-free extract ( $10 \mu \mathrm{l}$ ), dialysed supernatant fraction (Io $\mu \mathrm{l})$ or dialysed particulate fraction $(2.5 \mu \mathrm{l})$ in $90 \mathrm{mM}$-triethanolamine/ $\mathrm{HCl}$ containing

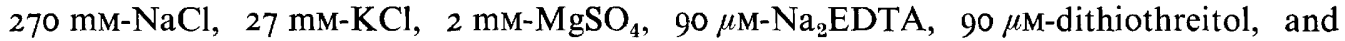
$2.7 \mu \mathrm{M}$-phenylmethylsulphonyl fluoride ( $\mathrm{pH} 8.0$ ), and either $20 \mu \mathrm{M}$ adenine, adenosine or AMP. AMP nucleosidase, adenosine nucleosidase and adenosine phosphorylase were assayed as described by Schramm \& Lazorik (I975) except that $2 \mu$ l dialysed cell-free extract was used in the above buffer system.

Degradation of radioactive substrates. Dialysed cell-free extract, supernatant fraction or particulate fraction ( $180 \mu \mathrm{l}$ ) was incubated for $30 \mathrm{~min}$ at $30^{\circ} \mathrm{C}$ and the reaction was then started by adding $50 \mu \mathrm{l}\left[\mathrm{U}-{ }^{14} \mathrm{C}\right] \mathrm{AMP},\left[\mathrm{U}-{ }^{14} \mathrm{C}\right] \mathrm{ATP}$ or $\left[\mathrm{U}-{ }^{14} \mathrm{C}\right]$ inosine $(\mathrm{I} 2.5 \mathrm{mM}$, I. $\left.6 \mathrm{mCi} \mathrm{mmol}^{-1}, \mathrm{pH} 8 \cdot 0\right)$ or $\left.50 \mu 1{ }^{32} \mathrm{P}\right] \mathrm{AMP}\left(12.5 \mathrm{mM}\right.$, about $\left.3 \mathrm{mCi} \mathrm{mmol}^{-1}, \mathrm{pH} 8 \cdot 0\right)$. Other nucleotides $(20 \mu \mathrm{l}, \mathrm{pH} 8.0)$ or buffer were added at the same time as the radioactive source. Samples $(20 \mu \mathrm{l})$ were removed at intervals and added to I $\mathrm{ml} 67 \%(\mathrm{v} / \mathrm{v})$ ethanol at room temperature. Ethanolic samples were immediately transferred to a water bath at $80{ }^{\circ} \mathrm{C}$ for $3 \mathrm{~min}$ and then removed to ice. They were rapidly freeze-dried $(<4 \mathrm{~h})$ and stored at $-22{ }^{\circ} \mathrm{C}$ until chromatographed.

Chromatography and radioactivity counting. Freeze-dried samples from experiments with ${ }^{14} \mathrm{C}$-labelled substrate were reconstituted with $0.25 \mathrm{ml}$ water and $5 \mu \mathrm{l}$ samples were spotted on to thin-layer cellulose plates (no. 6065 with fluorescent indicator, Eastman Kodak). When [ $\left.{ }^{32} \mathrm{P}\right] \mathrm{AMP}$ was used as the substrate an additional step was introduced to remove released inorganic $\left.{ }^{32} \mathrm{P}\right]$ phosphate, which interfered with the thin-layer chromatography. Freeze-dried samples were reconstituted with I $\mathrm{ml} 0 . \mathrm{I} \mathrm{M}-\mathrm{HCl}$ and applied to a $0.5 \times 0.5 \mathrm{~cm}$ column containing about I mg Norit A activated charcoal, which had been pre-treated to partially deactivate it by stirring with $15 \%(\mathrm{v} / \mathrm{v})$ octan-2-ol in ethanol followed by washing in ethanol, then water, and finally drying at $100{ }^{\circ} \mathrm{C}$ (Smith, Kelly \& Roy, 1974). After applying the labelled material to the column, it was washed with $5 \mathrm{ml} 0 . \mathrm{I} \mathrm{M}-\mathrm{HCl}$ and eluted with $2 \mathrm{ml}$ ethanol/ammonia (sp.gr. $0 \cdot 88$ )/water $(45: 5: 50$, by vol.). The eluate was 
spotted on to thin-layer plates. Chromatography and liquid scintillation counting were performed as described by Schramm \& Lazorik (1975).

Chemicals. ATP (disodium salt), CTP (type V), UTP (type I, sodium salt), ADP (grade I, sodium salt), AMP (type II, sodium salt), IMP (sodium salt), adenine, inosine, hypoxanthine, ribose 5-phosphate (disodium salt), octan-2-ol, 2,9-dimethyl-I, I0-phenanthroline hydrochloride, dithiothreitol, glycine, phenylmethylsulphonyl fluoride, triethanolamine hydrochloride, Tris (Trizma base) and activated charcoal (Norit A) were obtained from Sigma. $\left[\mathrm{U}-{ }^{14} \mathrm{C}\right] \mathrm{AMP},\left[\mathrm{U}-{ }^{14} \mathrm{C}\right] \mathrm{ATP}$ and $\left[\mathrm{U}-{ }^{14} \mathrm{C}\right]$ inosine were obtained from The Radiochemical Centre, Amersham. [ ${ }^{32}$ P]AMP was a gift from Dr R. Martin (University of Cambridge). GTP (trisodium salt) was obtained from Boehringer, adenosine (A grade) from Calbiochem, and 2,5-diphenyloxazole and I,4-di-2-(5-phenyloxazolyl)benzene (both scintillation grade) from Koch-Light. Whenever possible, all other reagents were of analytical grade; glass-distilled water was used throughout.

\section{RESULTS}

Spectrophotometric or colorimetric assays were made of several enzymes involved in AMP catabolism to determine which occur in B. natriegens. Only AMP deaminase [3.3,

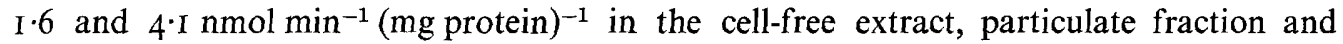
supernatant fraction, respectively] and adenosine deaminase [6.I, 4.3 and $8 \cdot 1 \mathrm{nmol} \mathrm{min}{ }^{-1}$ (mg protein $)^{-1}$, respectively] were found; the observed activities must be considered approximate due to the possibility of interfering cross-reactions. Adenine deaminase, AMP nucleosidase, and adenosine nucleosidase and phosphorylase activities were not detected.

Unfortunately, detection of these enzyme activities is insufficient to demonstrate the pathway of AMP catabolism. Furthermore, assays of this type cannot be used with crude extracts to determine whether AMP nucleotidase is present. In order to elucidate the AMP catabolic pathway(s), $\left[{ }^{14} \mathrm{C}\right] \mathrm{AMP}$ was added to extracts and the products were analysed.

When $\left[{ }^{14} \mathrm{C}\right] \mathrm{AMP}$ was catabolized by cell-free extracts in the absence of ATP there was a rapid build-up of inosine: no breakdown of inosine to hypoxanthine occurred and about $90 \%$ of the applied ${ }^{14} \mathrm{C}$ was recovered as inosine (Fig. 2a). Adenosine formation (up to $35 \%$ of the total ${ }^{14} \mathrm{C}$ ) preceded the appearance of inosine, suggesting that the primary route of AMP catabolism is via AMP nucleotidase and adenosine deaminase. However, some inosine could also be formed by the action of AMP deaminase plus IMP nucleotidase, with IMP not being detected due to the former enzyme having a lower activity under these conditions.

AMP catabolism was also measured in the particulate and supernatant fractions obtained by centrifuging the cell-free extract at $150000 \mathrm{~g}$ (Fig. 3). AMP was broken down about eight times more rapidly by the particles than by the supernatant fraction (Fig. $3 a, d$ ). Furthermore, the particulate fraction converted $85 \%$ of the AMP to adenosine before inosine was formed (Fig. $3 a$ ); thus AMP must be entirely catabolized by AMP nucleotidase and adenosine deaminase. In contrast, only about $40 \%$ of the ${ }^{14} \mathrm{C}$ was found as adenosine in the supernatant fraction (Fig. $3 d$ ), presumably due to the greater concentration of adenosine deaminase relative to AMP nucleotidase in this fraction.

Mammalian AMP deaminases are activated by ATP, yet inactivated by increases in energy charge in the 0.6 to 0.9 region (Burger \& Lowenstein, I967; Smith \& Kizer, 1969; Drummond \& Yamamoto, 197I; Chapman \& Atkinson, 1973). On the other hand, several AMP nucleotidases are inhibited by ATP (Burger \& Lowenstein, 1967; Woods et al., I970; Drummond \& Yamamoto, I97I). 


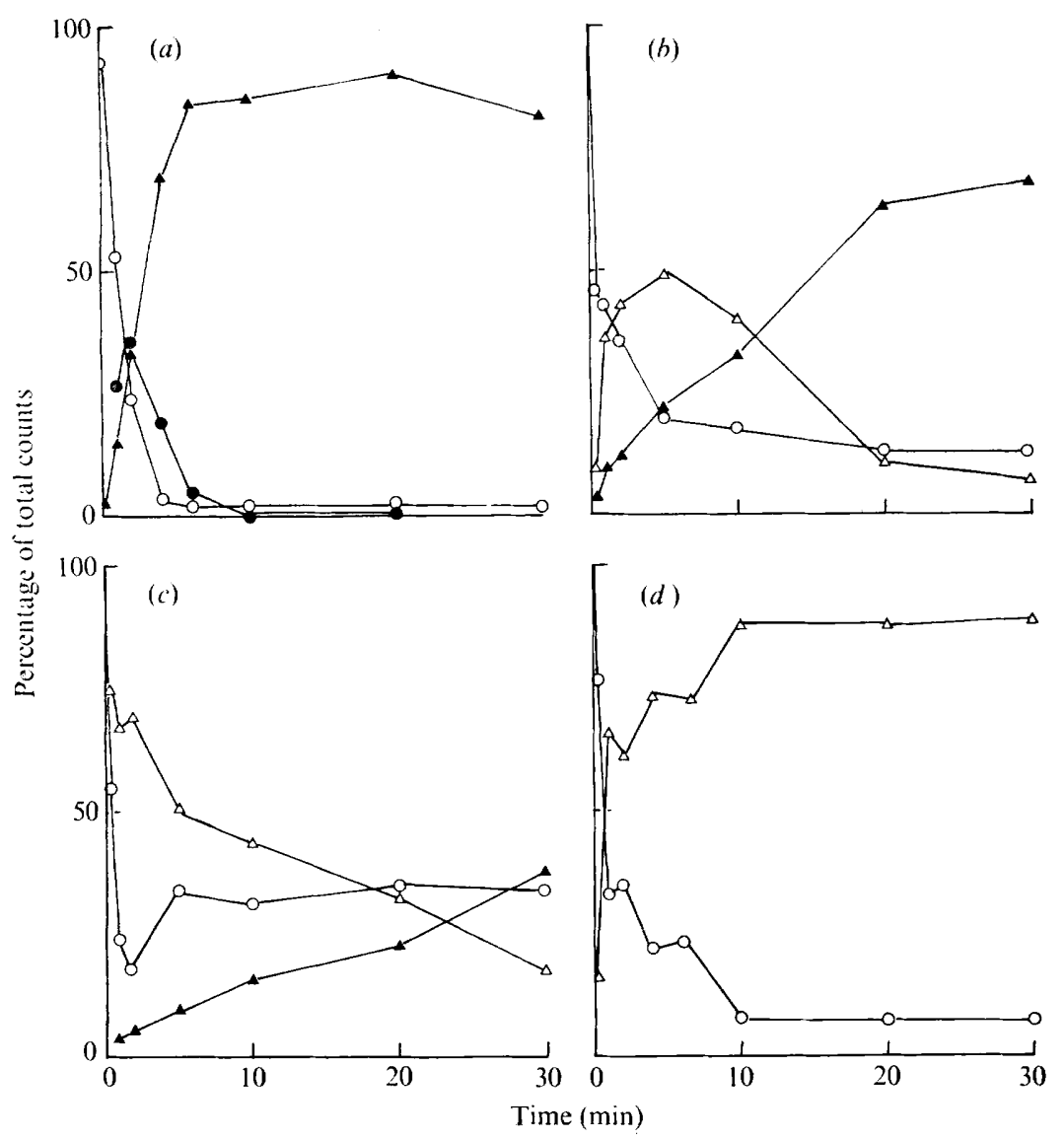

Fig. 2. The catabolism of $2.5 \mathrm{~mm}-\left[\mathrm{U}-{ }^{14} \mathrm{C}\right] \mathrm{AMP}$ by cell-free extracts of Beneckea natriegens in the absence of ATP $(a)$, and in the presence of ATP at $5 \mathrm{mM}(b), 10 \mathrm{mM}(c)$ and $40 \mathrm{mM}(d): \bigcirc, \mathrm{AMP}$; - adenosine; $\boldsymbol{\Delta}$, inosine; $\triangle$, IMP. No results are shown for ribose 5 -phosphate, hypoxanthine, adenine, and, where applicable, adenosine, IMP and inosine; for each of these compounds, counts were less than $6 \%$ of the total. Protein concentrations were $\left(\mathrm{mg} \mathrm{ml}^{-1}\right):(a) \mathrm{I} 2 ;(b),(c)$ and (d) 24 .

In preliminary experiments on the breakdown of I mM- $\left[{ }^{14} \mathrm{C}\right] \mathrm{ATP}$ by cell-free extracts of $B$. natriegens, the energy charge rapidly decreased from $\mathrm{I} \cdot 0$ to 0.3 and the ATP disappeared within a few minutes (not shown). Over $90 \%$ of the ${ }^{14} \mathrm{C}$ was recovered as inosine, after the intermediary formation of adenosine. However, despite this conversion of ATP to ADP and AMP by ATPase, adenylate kinase and other enzymes, the effect of ATP and/or high energy charge values on the catabolism of $\left[{ }^{14} \mathrm{C}\right] \mathrm{AMP}$ could be measured in the presence of $40 \mathrm{~mm}$ unlabelled ATP: during the period of the experiment only a small portion of the total ATP was converted to other adenylates and the energy charge and ATP content remained high.

In the presence of $40 \mathrm{mM}-\mathrm{ATP}, 2.5 \mathrm{mM}-\left[\mathrm{U}-{ }^{14} \mathrm{C}\right] \mathrm{AMP}$ was converted to IMP ( $>90 \%$ recovery of ${ }^{14} \mathrm{C}$ ) by cell-free extracts, suggesting the presence of an ATP-activated AMP deaminase (Fig. $2 d$ ). IMP was formed much more rapidly by the supernatant fraction than by the particulate fraction (Fig. $3 c, f$ ), indicating that this activity resides principally in the soluble fraction of the cell or is easily removed from the cytoplasmic membrane. 


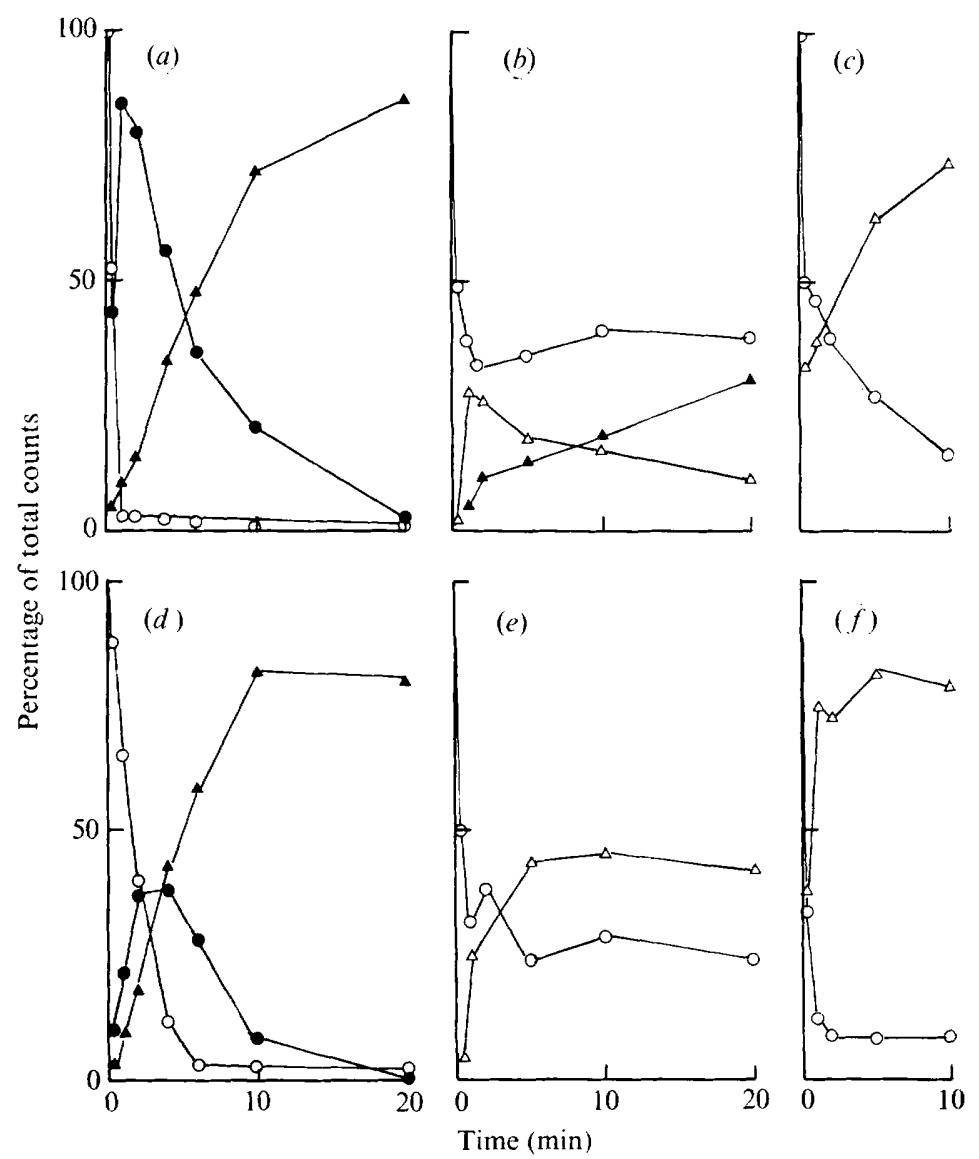

Fig. 3. The catabolism of $2.5 \mathrm{mM}-\left[\mathrm{U}-{ }^{14} \mathrm{C}\right] \mathrm{AMP}$ by the particulate $(a, b, c)$ and supernatant $(d, e, f)$ fractions of Beneckea natriegens in the absence of ATP $(a, d)$, and in the presence of ATP at $5 \mathrm{mM}(b, e)$ and $40 \mathrm{mM}(c, f): \bigcirc$, AMP; $\boldsymbol{O}$, adenosine; $\boldsymbol{\Delta}$, inosine; $\triangle$, IMP. No results are shown for ribose 5-phosphate, hypoxanthine, adenine, and, where applicable, adenosine, IMP and inosine; for each of these compounds, counts were less than 10\% of the total. Protein concentrations were $\left(\mathrm{mg} \mathrm{ml}^{-1}\right):(a) \mathrm{IO},(b) 2 \mathrm{I},(c) 28,(d) 23,(e)$ and $(f)$ 19.

With lower concentrations of ATP ( 5 and Io mM), IMP was formed in cell-free extracts and then converted to inosine (Fig. $2 b, c$ ) due to a significant decrease in ATP and/or energy charge, or an increase in inorganic phosphate during the course of the experiment. IMP nucleotidase must therefore also be present in $B$. natriegens. Like AMP nucleotidase, this enzyme is probably membrane-bound: in the presence of 5 mM-ATP, $\left[{ }^{14} \mathrm{C}\right] \mathrm{AMP}$ was degraded only to IMP by the supernatant fraction, but with the particulate fraction AMP was converted first to IMP, then to inosine (Fig. $3 b, e$ ).

Though the above data suggest that AMP is converted to IMP by an ATP-activated AMP deaminase, it is possible that the pathway could be AMP $\rightarrow$ adenosine $\rightarrow$ inosine $\rightarrow$ IMP, with the last step being catalysed by inosine kinase (EC 2.7.I .73). The absence of detectable intermediates (adenosine and inosine) and the distributions of the activities in the particulate and supernatant fractions argue against this possibility. Moreover, when cell-free extracts were incubated with $2.5 \mathrm{mM}-\left[\mathrm{U}-{ }^{14} \mathrm{C}\right]$ inosine in the presence of $40 \mathrm{mM}$-ATP, 70 to $77 \%$ of the ${ }^{14} \mathrm{C}$ remained as inosine after $30 \mathrm{~min}$, and 10 to $15 \%$ was found as 


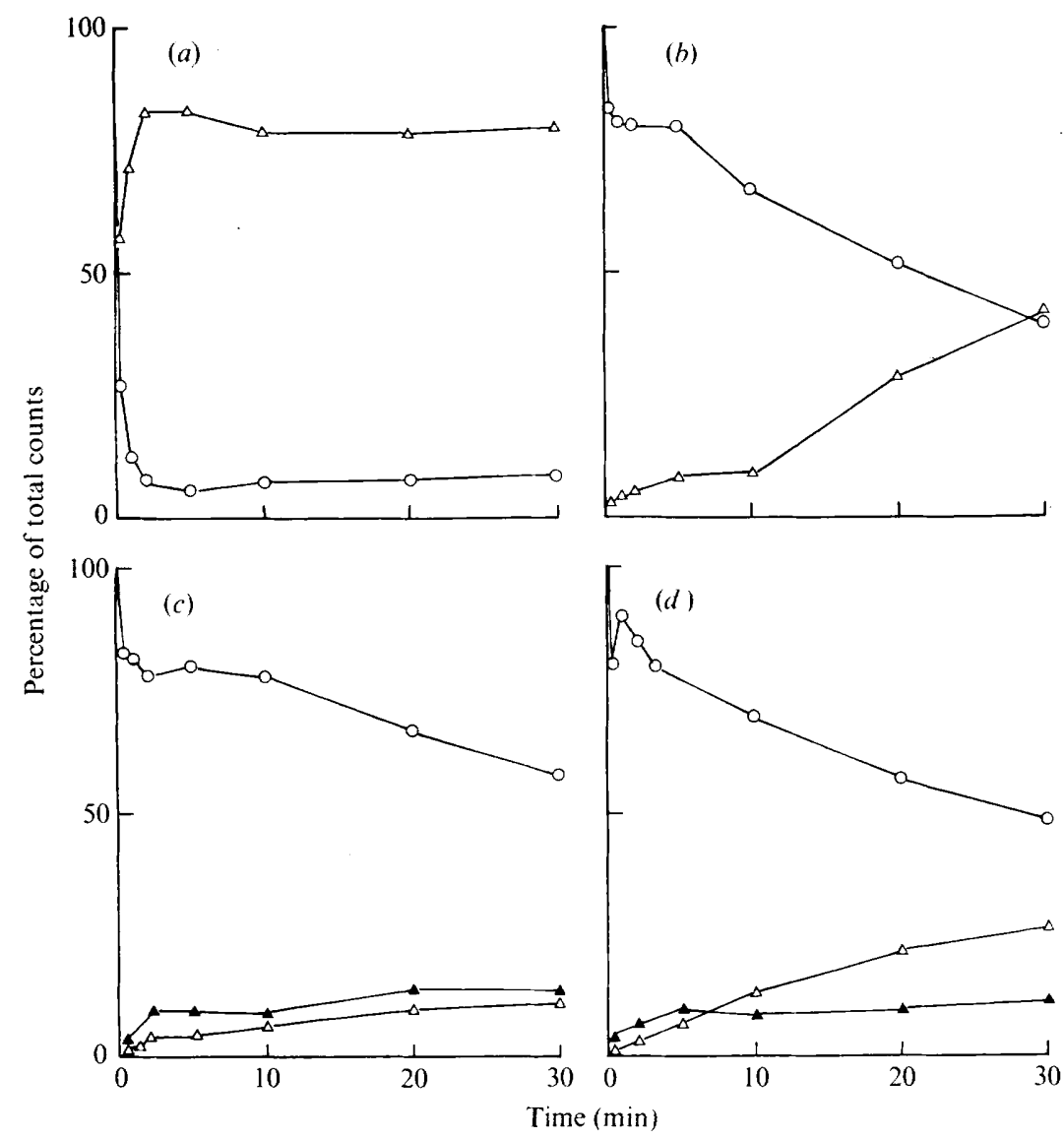

Fig. 4. The effects of (a) ATP, (b) GTP, (c) UTP and (d) CTP (each at $40 \mathrm{mM}$ ) on the catabolism of $2.5 \mathrm{mM}-\left[\mathrm{U}-{ }^{14} \mathrm{C}\right] \mathrm{AMP}$ by cell-free extracts of Beneckea natriegens: $\bigcirc$, AMP; $\boldsymbol{\Delta}$, inosine; $\triangle$, IMP. No results are shown for adenosine, ribose 5-phosphate, hypoxanthine, adenine, and, where applicable, inosine; for each of these compounds, counts were less than $6 \%$ of the total. Protein concentration was $16 \cdot 5 \mathrm{mg} \mathrm{ml}^{-1}$.

hypoxanthine. Less than $8 \%$ of the inosine was converted to IMP: therefore, inosine kinase is either absent or not active under these conditions.

If AMP is degraded to IMP by AMP deaminase, the phosphate group will be retained, but if the conversion is by AMP nucleotidase, adenosine deaminase and inosine kinase, then it will be lost and the $\gamma$-phosphate group of ATP will be introduced. When cell-free extracts, or particulate or supernatant fractions were incubated with $\left.2.5 \mathrm{mM}-{ }^{32} \mathrm{P}\right] \mathrm{AMP}$ in the presence of $40 \mathrm{mM}$-ATP, there was 87 to $94 \%$ conversion of the AMP to [ $\left.{ }^{32} \mathrm{P}\right]$ IMP within 2 to $5 \mathrm{~min}$. The retention of the labelled phosphate group in the resultant IMP is strong evidence for its direct formation by AMP deaminase.

AMP was only slowly degraded in the presence of GTP, UTP or CTP (Fig. 4), showing that these nucleotides inhibit AMP nucleotidase without significantly activating AMP deaminase. With GTP there was slow formation of IMP, but with UTP and CTP, IMP formation was followed by some inosine formation. Other AMP nucleotidases have have previously been shown to be inhibited by purine and pyrimidine nucleoside triphosphates (Drummond \& Yamamoto, I97I ; Felicioli et al., I973; Ipata et al., 1975). 


\section{DISCUSSION}

AMP was catabolized by extracts of $B$. natriegens, in the absence of ATP, to adenosine by a membrane-bound AMP nucleotidase, followed by conversion to inosine by a soluble adenosine deaminase. ATP inhibited AMP nucleotidase and stimulated AMP deaminase, which was found in the supernatant fraction of cell extracts, enabling AMP to be converted to IMP. When relatively low levels of ATP were used, IMP was subsequently degraded to inosine by a particulate IMP nucleotidase as the ATP level fell during the course of the experiment.

Since many 5 -nucleotidases convert several ribonucleoside phosphates (Hurwitz et al., 1957; Drummond \& Yamamoto, 1971; Felicioli et al., I973; Ipata et al., 1975), the AMP and IMP nucleotidase activities of $B$. natriegens possibly represent different functions of the same enzyme. AMP catabolism by extracts of $B$. natriegens is therefore remarkably similar to its catabolism by mammalian tissues (Burger \& Lowenstein, 1967; Woods et al., 1970; Drummond \& Yamamoto, 1971 ; Chapman \& Atkinson, 1973) and unlike its breakdown by AMP nucleosidase in $A$. vinelandii and $E$. coli (Schramm \& Leung, 1973; Schramm \& Lazorik, 1975).

To understand the metabolic function of the enzymes catalysing AMP breakdown, it is necessary to know their location within the bacterium. With cell sonicates of $B$. natriegens AMP deaminase was found in the supernatant fraction after centrifuging at $150000 \mathrm{~g}$ and AMP nucleotidase was found in the particulate fraction (Fig. 3). The latter enzyme is thus firmly membrane-bound and probably not a periplasmic enzyme, unlike the AMP nucleotidase of E. coli and several other bacteria (Heppel, I97I). Since the AMP deaminase of $B$. natriegens is in the supernatant fraction it could be either a cytoplasmic enzyme or easily leached from the membrane, i.e. possibly periplasmic. Unfortunately, because $B$. natriegens is a marine bacterium, requiring $\mathrm{Na}^{+}$and $\mathrm{Mg}^{2+}$ ions for cellular integrity, it is not possible to use osmotic shock techniques or to form sphaeroplasts using lysozyme/ EDTA/sucrose to release periplasmic enzymes (cf. Heppel, 197I), since such treatments cause lysis.

At this stage one can only speculate why AMP is catabolized by these pathways in B. natriegens. Presumably either AMP nucleotidase or AMP deaminase is involved in regulation of the total adenine nucleotide content during growth, like rat liver AMP deaminase and $A$. vinelandii AMP nucleosidase (Chapman \& Atkinson, 1973; Schramm \& Leung, 1973; Knowles, 1977). However, B. natriegens is unlike E. coli and possibly other bacteria in that when there is a plentiful supply of substrate, but it is unable to grow due to depletion of the nitrogen source, there is a rapid increase in the intracellular adenine nucleotide pool size (Chapman et al., I97I; Niven et al., 1977; Knowles, 1977). This could be due either to an increased rate of de novo synthesis of AMP or, more likely, to a decreased net rate of adenine nucleotide consumption for macromolecular synthesis and an increased rate of salvage of AMP from RNA degradation. The ATP-activated AMP deaminase activity would be a method of controlling the adenine nucleotide content, or a way of regenerating scarce ammonia-nitrogen for other use. On the other hand, when the ATP pool size and energy charge fall due to starvation (Niven et al., 1977), AMP could be degraded by the ATP-inhibited AMP nucleotidase in order to provide a carbon source and to maintain the energy charge.

To determine whether these speculations are valid, or whether there are other reasons for the pathways of AMP breakdown by B. natriegens, we are currently purifying the AMP catabolic enzymes to determine their catalytic and regulatory properties. 
This investigation was supported by a grant from the Science Research Council. We wish to thank Dr Vern Schramm (Temple University) for helpful discussions and Dr Rick Martin (Cambridge University) for kindly supplying [ $\left.{ }^{32} \mathrm{P}\right] \mathrm{AMP}$.

\section{REFERENCES}

AtKInSON, D. E. (1968). The energy charge of the adenylate pool as a regulatory parameter. Interaction with feedback modifiers. Biochemistry 7, 4030-4034.

Boosman, A. \& Chilson, O. P. (1976). Subunit structure of AMP-deaminase from chicken and rabbit skeletal muscle. Journal of Biological Chemistry 25I, I847-1852.

Burger, R. \& Lowenstein, J. M. (1967). Adenylate deaminase. III. Regulation of deamination pathways in extracts of rat heart and lung. Journal of Biological Chemistry 242, $528 \mathrm{I}-5288$.

Chapman, A. G. \& AtKInson, D. E. (I973). Stabilization of adenylate energy charge by the adenylate deaminase reaction. Journal of Biological Chemistry 248, 8309-83 2.

Chapman, A. G., Fall, L. \& AtKinson, D. E. (1971). Adenylate energy charge in Escherichia coli during growth and starvation. Journal of Bacteriology 108, 1072-1086.

Drummond, G. I. \& Yamamoto, M. (197I). Nucleotide phosphomonoesterases. In The Enzymes, vol. 4, 3rd edn, pp. 337-354. Edited by P. D. Boyer. London and New York: Academic Press.

Felicioli, R. A., Senesi, S., Marmocchi, F., Falcone, G. \& Ipata, P. L. (1973). Nucleoside phosphomonoesterases during growth cycle of Bacillus subtilis. Biochemistry 12, 547-552.

Gornall, A. G., Bardawill, C. J. \& David, M. M. (1949). Determination of serum proteins by means of the biuret reaction. Journal of Biological Chemistry 177, 751-766.

HePPEL, L. A. (I97I). The concept of periplasmic enzymes. In Structure and Function of Biological Membranes, pp. 223-247. Edited by L. I. Rothman. London and New York: Academic Press.

Hurwitz, J., Heppel, L. A. \& Horecker, B. L. (I957). The enzymatic cleavage of adenylic acid to adenine and ribose 5-phosphate. Journal of Biological Chemistry 226, 525-540.

ipata, P. L., Palmarini, C. A., Senesi, S., Falcone, G. \& Felicioli, R. (1975). The role of nucleoside triphosphates in the control of $3^{\prime}$ - and 5'-AMP dephosphorylation in crude extracts of $B$. subtilis. FEBS Letters 57, 195-197.

KNOWLES, C. J. (1977). Microbial metabolic regulation by adenine nucleotide pools. Symposia of the Society for General Microbiology 27, 24 I-283.

KoCH, A. L. \& VAlLeE, G. (I959). The properties of adenosine deaminase and adenosine nucleoside phosphorylase in extracts of Escherichia coli. Journal of Biological Chemistry 234, $1213-1218$.

KoHN, J. \& ReIs, J. L. (I963). Bacterial nucleotidases. Journal of Bacteriology 86, 7I 3-716.

Makarewicz, W. \& StankIEWICZ, A. (1976). Purification of AMP-deaminase from human skeletal muscle on 5'-AMP Sepharose 4B. International Journal of Biochemistry 7, 245-247.

Niven, D. F., Coluins, P. A. \& KNowles, C. J. (1977). Adenylate energy charge during batch culture of Beneckea natriegens. Journal of General Microbiology 98, 95-108.

Schramm, V. L. \& LAzorik, F. C. (1975). The pathway of adenylate catabolism in Azotcbacter vinelandii. Evidence for adenosine monophosphate nucleosidase as the regulatory enzyme. Journal of Biological Chemistry 250, I80 r-I 808 .

Schramm, V. L. \& Leung, H. (1973). Regulation of adenosine monophosphate levels as a function of adenosine triphosphate and inorganic phosphate. A proposed metabolic role for adenosine monophosphate nucleosidase from Azotobacter vinelandii. Journal of Biological Chemistry 248, 831 3-8315.

SMITH, H. O., KeLLY, T. J. \& Roy, P. H. (I974). Enzymatic methods for sequence analysis applied to DNA restriction and methylation sites. Methods in Enzymology 29, 282-294.

Smith, L. D. \& Kizer, D. E. (1969). Purification and properties of rat liver AMP deaminase. Biochimica et biophysica acta I9I, 415-424.

Weston, J. A. \& KNOWLES, C. J. (1973). A soluble CO-binding $c$-type cytochrome from the marine bacterium Beneckea natriegens. Biochimica et biophysica acta $305, \mathrm{I}$ - 18 .

Weston, J. A. \& KNOWLES, C. J. (1974). The respiratory system of the marine bacterium Beneckea natriegens. I. Cytochrome composition. Biochimica et biophysica acta 333, 228-236.

Woods, H. F., EgGleston, L. V. \& KREBS, H. A. (1970). The cause of hepatic accumulation of fructose-Iphosphate on fructose loading. Biochemical Journal I19, 50I-510.

YAGIL, E. \& BEACHAM, I. R. (1975). Uptake of adenosine 5'-monophosphate by Escherichia coli. Journal of Bacteriology 121, 40I-405.

YATES, M. G. (I969). A non-specific adenine nucleotide deaminase from Desulfovibrio desulfuricans. Biochimica et biophysica acta 171, 299-310. 